\title{
The Importance Of Oral Presentations For University Students
}

\author{
Slađana Živković, PhD \\ College of Applied Technical Sciences \& Faculty of Civil Engineering and Architecture, \\ University of Niš, Serbia \\ sladjanazivkovic.ni@gmail.com
}

DOI:10.5901/mjss.2014.v5n19p468

\begin{abstract}
This paper aims at presenting the specifics of designing oral presentations for university students. Oral presentations are becoming an important part of language teaching, especially in the university environment. Teaching students to design effective oral presentations presupposes two goals, namely, enabling students to function successfully in the future professional surrounding, and preparing them for their possible further academic career. For both directions, the author of this text, an ESP lecturer and syllabus designer, concludes from her own teaching experience that teaching presentations is a necessity if students are to perform well both in professional and academic settings. Since oral presentations involve multiskills, a carefully planned and constructed guideline will help develop students' receptiveness to oral presentations. By making students aware of basic points, types, characteristics and styles of scientific and technical communication, the paper is to serve as a starting point in an attempt to make them expand and perfect their oral presentation skills. In a pilot study a conceptual framework has been used to illustrate our starting point. It has been examined the importance of designing an effective oral presentations at the university level.
\end{abstract}

Key words: oral presentations, university students, professional and academic settings

\section{Introduction}

The present paper concentrates on oral presentations designed to help university students to improve their communicative skills.

"Today's challenging economic situation means that it is no longer sufficient for a new graduate to have knowledge of an academic subject; increasingly it is necessary for students to gain those skills which will enhance their prospects of employment" (Fallows \& Steven, 2000). Employability skills include the following abilities: the retrieval and handling of information; communication and presentation; planning and problem solving; and social development and interaction, creative thinking, problem solving critical thinking, active and reflective application of knowledge (Fallows \& Steven, 2000; Driscoll, 2000). These are the skills students need to succeed in their future workplace, so, they should be embedded within the academic curriculum.

One especially relevant part of language curriculum at universities is teaching students how to prepare, organize and deliver successful oral presentations for professional purposes. Oral presentations provide "a rewarding and stimulating experience both for teachers in developing facilitating skills and for students in training themselves to have confident presentations in public" (King, 2002).

\section{The importance of designing effective oral presentations}

The ability to communicate is the most important goal that communicative language teaching aims to reach. It is to be able to operate effectively in the real world (Hedge, 2000). Students need a lot of opportunity to practice language in situations which encourage them to communicate their needs, ideas and opinions. With globalization graduates need to be proficient in oral communication skills in order to function effectively in the professional setting (Živković \& Stojković, 2011). Generally, effective oral communication is essential for success and promotion in business (Murphy and Hildebrand, 1997).

For successful oral communication students need a thorough in-depth instruction and practice. The best practice is to give oral presentations. Oral presentation skills are essential for employability and true academic study as they lead students to enter into debate and sustained reasoning (Morley, 2006). They enable students to participate fully in their 
learning, demonstrate their ability to communicate, and help them develop competencies in an area of their future working places. They demonstrate one of the most successful way "to get the student's attention, encourage curiosity, create challenges" (Hutchinson and Waters, 1987).

The study of presentation techniques is a chance for students to gain insight into knowledge and skills that make a good lecturer which often turns to become their vocation. The mastery of the subject topic and the good will to interact with others will allow them to actually enjoy sharing their knowledge in a constructive way both for their audience and themselves with structured planning and organization.

Teaching principles of oral presentations at university level is an especially relevant curriculum segment and is done with the ultimate purpose of better communicating professional knowledge to other professionals and to non specialists (Živković \& Stojković, 2013). Every professional is involved in some aspects of communication which usually involve gathering, analyzing, and distributing scientific and/or technical information efficiently and accurately for specific audiences.

Teaching students to design effective presentations implies developing their insightful and well-trained thinking strategies that can produce clarity in communication without oversimplifying scientific or vocational issues. The results are substantive, which means improving the quality of presentation actually improves the quality of thought, and vice versa.

Students can gain knowledge not only from the research they and other students perform, but also by observing the other presenters' strengths and weaknesses to develop better communication and presentation skills" (Girard \& Trapp, 2011). According to Girard \& Trapp (2011) the potential benefits of students' oral presentations include:

greater class interaction and participation,

increased interest in learning,

new perspectives not covered otherwise,

improvement in communication and presentation skills. 2002).

Oral presentations represent an opportunity for developing real-world communications as well as leadership skills (King,

Among the many advantages of designing oral presentations for students are (King, 2002):

bridging the gap between language study and language use;

using the four language skills in a naturally integrated way;

helping students to collect, inquire, organize and construct information;

enhancing team work;

helping students become active and autonomous learners.

Students are involved in their own learning process as active participants, they are engaged in real-world experience, and they build creative and critical thinking and problem-solving skills as important characteristics for success in the 21st century. The final goal is to help students maximize their potential, both personally and professionally.

\section{Supporting students to develop better communication and presentation skills}

Gray (2010) argues that communication skills must be transferred from the classroom to the workplace. Today's business graduates are expected to have solid communication skills. Graduates are expected to enter industry with the ability to communicate effectively. In that way, university must provide students with communication skills demanded by employers (Russ, 2009). Communication skills are required by students (future specialists) whether they are expected to give presentations at conferences, symposia or other meetings. In order to be effective communicators, innovators, critical thinkers and problem solvers today's students "enhance their skills and capacities by improving their means of linking their skills and capacities to the world market" (Reich, 1991). Because of the necessity for these skills, students need instructions and guidance in preparing, organizing and delivering oral presentations.

Students' oral presentations are a common part of many courses at colleges and universities as they are one of the ways to improve learning of course material. Despite the positive aspects of using presentations in the classroom, some students may show resistance to do extra work, have fear in public speaking, and display boredom while sitting through 
others' presentations if they are not engaged with the experience. Therefore, such students may have generally negative beliefs about giving classroom presentations (Girard \& Trapp, 2011).

But, on the other hand, if properly guided and organized, oral presentations provide a learning experience and teach lifelong skills that will be beneficial to students in all school subjects, and later in their careers (Meloni \& Thompson, 1980).

\section{Basic instructional design}

Since oral presentations involve multi-skills, a carefully planned and constructed guideline will help develop students' receptiveness to these presentations. Listing instructional objectives and explaining reasons for this activity can increase student participation and may always result in a heightening of satisfaction and achievement.

The fundamental purpose of scientific discourse is not the mere presentation of information and thought, but rather its actual communication (Gopen, 1990). The fact is that oral presentations are much more than a simple delivery of one's scientific of professional knowledge. The preconditions of an effective, but most importantly good oral presentations are many. Sole mastery of the required knowledge is insufficient in this case. The success largely depends on judging all the specifics of the situation and responding to those properly, and the impression one gives as a person. An oral presentation should never be a monologue, but an active dialogue in which verbal communication is not the only constituent.

The content element of the presentation includes aspects that need to be assessed such as knowledge shown, logical appeal, fielding of objections, questions posed, improvisation shown, and conclusion (Carroll, 2005). Separating your presentation into meaningful sections achieves some of the cognitive work for your audience (Platow, 2002).

The important aspects of spoken presentations are the following:

1. Introduction,

2. The main body (Methods, Results),

3. Conclusion (Discussion).

1. Introduction - Greet the audience, Introduce yourself, Explain the purpose of your talk - Start by introducing the topic, Outline the main points - State your purpose and announce the outline of your presentation in very simple, precise language. A good introduction will capture an audience's attention.

2. The main body (methods, results) - Move to a point - outline your talk, State main ideas clearly and present examples, Introduce a visual aid Use visual aids to engage the interest of your audience. The information in the body needs to be well-structured. Decide on an organizing principle. It could be by chronological order, theme or order of importance.

3. Conclusion (Discussion) - Conclude your talk, Summarize the main points, Invite questions and comments.

The facts that need close attention are the following:

\section{a. Identify the audience}

The first thing to be done when preparing a spoken presentation is to identify the audience as precisely as possible (experts, technicians, executives, nonspecialists). Different audiences require and are prepared for different amount and depths of information. The success of a presentation depends on knowing those in advance.

\section{b. Determine the aims of presentation}

The presentation can have one of these aims: to inform, to persuade, to teach. Depending on these, the structure and the shape of the presentation will vary significantly.

\section{c. Shape the presentation}

Students should gain the mastery of organizing and selecting their arguments or pieces of information so as to respect the time allotted. Also, for the sake of their assertiveness they should familiarize themselves with the physical space for their presentation and visualize their movements within. The organization will depend on the overall purpose of the talk, but basically it may be of the following kinds: classifications, cause and effect, problem and solution, experimentation.

d. Introduce appropriate visual aids. The main thing is to encourage students to use support material and visual aids. When designing a visual, students should consider its effect on the audience. To help the audience follow the presentation, it is 
a good idea to use some of the visual aids: Slides, LCD and DLP Projectors, Laptops, LCD panels, Video, Multimedia, Laser Pointers, Lapel Microphones. There are a great many presentation tools available to presenters. "Even the simplest visual aid can provide a grasp of the structure and direction of the argument, which will help the listeners to understand and remember" (Turk, 1985).

Some advantages of using the visual aids (Walters and Walters, 2002):

they can contain more details,

they are good for audience participation,

they can show motion,

they are easy to modify or create,

they keep room lights up,

- they can be a concrete reminder of the message.

\section{e. Gain the audience's attention}

The introduction must draw the audience's attention, identify the topic, and create expectations in the audience that the presenter will satisfy in the course of the presentation. Gain the audience's attention by connecting their needs/values/knowledge to the topic of the speech.

f. Familiarise the audience with the aim, content, and the structure of presentation

The audience should know what to expect and should be immediately persuaded that these expectations will be fulfilled. This requires clear statement of the content organization at the very beginning.

\section{g. Prepare a closing summary}

An effective conclusion develops naturally from the structure and content of the preceding material. It reaffirms the connection between the audience and the material presented.

\section{h. Delivery}

During the presentation a presenter need to:

- face the audience - maintain eye contact with the audience as much as possible,

- use natural hand gestures,

- look presentable - it means to dress well for the presentation, usually a formal outfit is preferred to show the level of professionalism. Appearance says a lot about someone's personality and confidence,

- speak in a clear and audible voice to get your presentation through to the audience even the ones sitting further away,

- pause periodically - it gives your audience a chance to digest your information and it also gives them permission to participate,

- be aware that nervousness is to be expected, just should be turned into enthusiasm,

- Engage your audience - pose a question to see how much they know about the subject you are about to discuss,

- give the talk a clear, logical structure with an introduction, the main body and a conclusion,

- emphasize key words to allow your audience what they really need to pay attention to; if you speak in the same voice tone throughout the entire presentation, no one knows what is really important.

- make the visual aids clear and easy to understand,

- respond to questions politely, good-humoredly, and briefly,

- summarize your main points and give a strong concluding remark that reinforces why your information is of value.

-- invite questions from the audience at the conclusion of your presentation. A well-managed questions and answers at the end of the presentation are of real value. Encourage the presenting student to invite questions and the audience to ask them. 
As a well-known fact, English language instruction today is often one of the crucial aspects of preparing students for their vocation in a highly competitive international professional environment. Teaching principles of oral communications at university level is an especially relevant curriculum segment and is done with the ultimate purpose of better communicating professional knowledge to other professionals. Every professional is involved in some aspects of communication which usually involve gathering, analyzing, and distributing scientific and/or technical information efficiently and accurately for specific audiences.

As a summary to all mentioned above, it is important to point out that oral presentations for academic and professional purposes need to occupy a significant part of language teaching classes. By their nature they can be taught only as an interactive kind of lecturing. Through practice work students reproduce the knowledge lectured through their own examples. The aim of such classes is practical and concrete. It is tailored according to the needs of specific professions and allows students to present the acquired academic knowledge in both academic and professional environment

How oral presentations can be effectively integrated among university students

In a pilot study a conceptual framework has been used to illustrate our starting point. The study has grown out of a large research project investigating the significance of oral presentations in engineering classrooms.

It has been examined how students comprehend the importance of oral presentations in the engineering course. The investigation was performed at the Faculty of Civil Engineering and Architecture in Niš, based on the sample of 85 students. The collecting of data was done in the spring semester, March, 2014. Data analysis was carried out through qualitative analysis technique. It has produced insightful results into students' perceptions of the importance of classroom oral presentations.

\section{A questionnaire method}

For the purpose of the current study, a questionnaire method on students' attitudes (opinions, preferences and reactions) towards the significance of oral presentations in the engineering classroom has been developed. It has been investigated the impact of oral presentations on students' performance in English classes. It aims at finding students' attitudes towards the use of oral presentations in the classroom. Finally, it is to provide teachers with some suggestions to make best use of oral presentations in their teaching with a view to enhance students' speaking skills.

\section{Results}

The research project has investigated students' perceptions of the development of their communication skills during the course. The results obtained in the study show that students perceive the significance of preparing and delivering oral presentations for successful communication in the future professional surrounding. Students' attitudes toward the use of oral presentations in English lessons can be summarized as follows:

- Students report that communication classes are more interesting and effective compared to the traditional ones. Unlike the traditional classroom model (i.e. teacher-centered pedagogy), student-centered learning requires students to take an active role in forming new understandings, and are not just passive receptors (Dunlap \& Grabinger, 1995).

- Students find the importance of developing successful communication. Being able to communicate effectively is the challenge of the current global job market. Communicating and thus connecting with colleagues and business partners is an essential skill in career development.

- Students report that through collaboration with colleagues they are engaged in learning that is authentic, holistic, and challenging. Importantly, through collaboration with their colleagues, students develop skills that prepare them to deal with situations and problems they will encounter in the workplace.

- Students claim that discussions within the class provide them with the opportunity to practice sharing their experiences with their colleagues. According to Kennedy (2007) in-class debates are a means (for students) to cultivate both critical thinking and oral communication skills.

- They share ideas with each other and help each other build elaborate and refined knowledge structures (Dunlap \& Grabinger, 1995). They will have to present new ideas or progress reports to their colleagues, or they will share the findings of their researches with their peers (Platow, 2002). This is contrary to traditional classroom settings in which learning is based on repetition of activities, and the subjects are guided by a textbook only. 
- Students (future specialists) are aware of the fact that knowledge is not enough to be successful in today's world. They report they are given the chance to promote creativity and innovation by giving oral presentations. They are allowed to explore different perspectives and ways of looking at problems. The development of these skills is important for students to be able to solve the complex problems facing society in the future.

- Students comment that there are various ways of demonstrating their learning in the classroom. The potential benefits of such activities include greater class interaction and participation, increased interest in learning and improvement in communication. More specifically, rich learning activities help students think deeply about content in relevant and realistic contexts (Dunlap \& Grabinger, 1995).

- Students state they enjoy these courses including activities which help their understanding of the importance of oral presentations. Students should be encouraged to search for solutions to real-world problems, and thus, they are engaged in transformative learning, leading to critical and analytical thinking which is essential for success in the 21 st century.

- Students improve their organizational skills by creating oral presentations. The teacher helps them to provide needed structure, assists in becoming organized, and supports critical skills.

- Students argue that being able to make effective presentations will highlight their leadership which is important in building a successful career.

- Finally, students agree that it is a new experience and the best way to create new knowledge.

All in all, students have a very positive attitude towards oral presentations in the classroom. In fact, they are highly positive in their beliefs about benefits and usefulness of doing oral presentations. They agree that doing oral presentations helps them learn English better and practice their speaking skills.

\section{Discussion}

This pilot study has reported on well-designed oral presentations which enable students to function successfully in the future professional surrounding. It presents a challenge to both students and the teacher.

The challenge for the teacher is to provide a relevant framework for students upon which they construct knowledge and become active participants in the learning process. The teacher involves preparing detailed guidelines, organizing groups, helping students to select topics, guiding their research and helping them learn the use of various visual aids, providing feedback on the sequencing of ideas, and evaluating their performance (King, 2002). Importantly, the teacher is no longer perceived as the knowledge dispenser and decision maker. Instead, the teacher has become the facilitator of learning whose main task is to set goals and organize the learning process accordingly. The teacher creates social and intellectual climates, where collaborative and cooperative learning methods are supported. The teacher creates opportunities for students to interact with other learners and with the teacher as well. On the whole, the teacher is responsible for leading and coordinating the work and make learning progress easier.

Besides, the teacher is the supporter, one who supports the learner by means of suggestions that arise out of ordinary activities, by challenges that inspire creativity, and with projects that allow for independent thinking and new ways of learning information.

In Vygotsky's (1978) theory of constructivism, the teacher serves as the mediator who coaches and encourages students to formulate their own level of understanding.

In the Bruner's (1979) classroom, the teacher is the instructor, (direct and guide the learning process) who should try and encourage students to discover principles by themselves. The teacher and students should engage in an active dialog (Socratic learning).

Moreover, there is a demand for the teacher in the classroom not to be only a guide, organizer, instructor, mediator and supporter, but, as King (2002) comments, to hold questions and answers sessions, provide feedback, and evaluation of students performance.

We have to agree with Crystal (2003) who claims that the actor and the teacher inhibit the same stable. They both have to put on a show (the actor on a stage and the teacher in the classroom).

On the other hand, students function as designers using the technology as tools for analyzing the world, accessing information, interpreting and organizing their personal knowledge, and representing what they know to others (Jonassen, 1994). Students must be given opportunities to be active in ways that will promote self-direction, creativity and critical 
analysis of problems requiring a solution (Jonassen, 1994). "Learning becomes a continuous, life-long process which results from acting in situations" (Brown et al., 1989).

It has been observed by Kim et al. (1999) that students have more positive attitude towards learning as they share their experiences with their peers and the teacher, as well as they experience increasing discussions in the classroom. Brown (1996) has proved that oral presentations help students to work collaboratively and make it easier to focus on a specific area useful for future work.

Students are encouraged to search for solutions to real-world problems, and thus, they are engaged in transformative learning, leading to critical and analytical thinking which is essential for success in the 21 st century.

\section{Conclusion}

Today's global, competitive and rapidly changing world needs young people who are flexible, active, innovative and creative in problem solving and decision making, who can communicate effectively and work collaboratively. It needs young people to develop their potential as individuals and to be prepared for the unique demands of the 21 st century world. The ability to communicate is important in order to be able to operate effectively in the real world (Hedge, 2000).

Students need a lot of opportunity to develop and practice communication skills. Communication skills are required by students (future specialists) whether they are expected to give presentations at conferences, symposia or other meetings. Because of the necessity for these skills, students need instructions and guidance in preparing, organizing and delivering oral presentations. Oral presentations have become a useful and effective way to increase students' awareness of communication skills. Thus, students' presentations become an important element in delivering positive learning experiences. They are an integral part of almost every professional environment, as professionals need to communicate with other professionals at meetings, seminars, conferences.

So, teaching students to design effective oral presentations implies training them insightful and well-trained thinking strategies. Improving the quality of presentation actually improves the quality of thought, and vice versa. This is the ultimate result of a successful presentation. This innovative framework provides a holistic approach in assessing a student's performance based on the content and the delivery of their presentation (Carroll, 2006).

\section{References}

Brown, J. S., Collins, A., \& Duguid, P. (1989). "Situated cognition and the culture of learning". Educational Researcher, 18 (1), 32-41.

Brown, D. L. (1996). Kids, computers and constructivism. Journal of Instructional Psychology, 23 (3), 189-196.

Bruner, Jerome. Actual Minds, Possible Worlds. Cambridge, MA: Harvard University Press, 1986.

Carroll, C. (2005). "Assessing Project-Based Learning: A case study of an undergraduate selling and sales management module at the

University of Limerick" in Barrett, T., Mac Labhrainn, I., Fallon, H. (Eds). Handbook of Enquiry and Problem-based Learning. Galway: All Ireland Society for Higher Education, and Centre for Excellence in Learning and Teaching, NUI Galway, pp.95102.

Carroll, C. (2006). Enhancing Reflective Learning through Role-Plays: The Use of an Effective Sales Presentation Evaluation Form in Student Role-Plays. Marketing Education Review, 16 (1), 9-13.

Crystal, D. (2003). English as a global language (2nd ed). Cambridge: Cambridge University Press.

Driscoll, M. P. (2000). Psychology of Learning for Instruction. (2nd ed.). Needham Heights, MA: Allyn \& Bacon.

Dunlap, J, C., \& Grabinger, S. (1996). "Rich Environments for Active Learning in Higher Education". Constructivist Learning Models in

Higher Education. B.G. Wilson (ED.) Englewood Cliffs, Educational Technology Publication: NJ.

Fallows, S. \& Steven, C. (2000). Building Employability Skills into the Higher Education Curriculum: A University-wide Initiative. Education\& Training, 42(2), 75-83. 
Girard, M. P., \& Trapp, P. (2011). "An exploratory study of class presentations and peer evaluations: Do students perceive benefits?"

Academy of Educational Leadership Journal, vol. 15, no. 1, pp. 77-94.

Gopen, G. D., \& Swan J. A. (1990). The Science of Scientific Writing. American Scientist, Volume 78, 550-558.

Gray, F. E. (2010). Specific Oral Communication Skills Desired in New Accountancy Graduates. Business Communication Quarterly, 73(1), 40-67.

Hedge, T. (2000). Teaching and Learning in the Language Classroom. Oxford: OUP.

Hutchinson, T., \& Waters, A. (1987). English for specific purposes. Cambridge: CUP.

Jonassen D. H., (1994). Thinking technology: Towards a Constructivist Design Model, Educational Technology, April, 3437

Kennedy, R. (2007). In-Class Debates: Fertile Ground for Active Learning and the Cultivation of Critical Thinking and Oral Communication Skills. International Journal of Teaching and Learning in Higher Education,19(2), 183-190.

Kim, H. B., Fisher, L. D., \& Fraser, J. B. (1999). Assessment and investigation of constructivist science learning environment in Korea.

Research in Science and Technological Education, 17 (2), 239-249

King, J. (2002). Preparing EFL learners for oral presentations preparing. Journal of Humanistic Studies, 4, 401-418.

Meloni, C., \& Thompson, S. (1980). Oral reports in the intermediate ESL classroom. TESOL Quarterly, 14 (4), 503-510.

Morley, L. 2001. Producing New Workers: Quality, Equality and Employability in Higher Education. Quality in Higher Education, 7(2),

pp.131-138.

Murphy, H. A., Hildebrandt, H.W., \& Thomas, J.P. (1997). Effective Business Communications. 7thEdition, New York: McGraw-Hill.

Platow, J. M. (2002). Giving professional presentations in the behavioral sciences and related fields. New York: Taylor \& Francis Books, Inc.

Reich, R. (1991). The work of nations: Preparing ourselves for 21st century capitalism. New York: Knopf.

Russ, T. (2009). The status of the business communication course at U.S. colleges and universities. Business Communication Quarterly, 72 (4), 395-413. Retrieved from http://www.bcq.theabc.or

Turk, C. (1985). Effective Speaking, Communicating in Speech. London: Chapman \& Hall.

Walters, E. D., \& Walters, G. C. (2002). Scientists Must Speak: Bringing Presentations to Life. London: Routledge Study Guide.

Živković, S., \& Stojković, N. (2011). Modernization of English as Foreign Language Studies in University Education, in University

Education in Transition, Transition in University Education - Modern and Universal, Belgrade, pp. 213-223.

Živković, S., \& Stojković, N. (2013). To Modernize or not to Modernize - There is no Question. Academic Journal of Interdisciplinary Studies. Rome-Italy: MCSER Publishing. 